\title{
THE ISLAMIC WEALTH MANAGEMENT: AN ANALYSIS FROM IBN SĪNĀ'S PERSPECTIVE
}

\author{
Nurizal Ismail \\ Dr. Muhammad Syafii Antonio
}

\begin{abstract}
This study aims to present the economic ideas of Ibn-e-Sīnā, dealing with the concept of wealth management. In order to achieve its objectives, this study employs qualitative research that refers to the meanings, concepts, definitions, characteristics, metaphors, symbols and descriptions of the matter under study. The study uses the literatures of Ibn Sinnā related to tadbir al-manzil (economics) to develop a theoretical model of managing wealth that integrates the material, spiritual, moral, social and legal dimensions. There are two methodologies of this study, namely interpretative and historical analytic methods. In his wealth management, there are two main variables; kasb (earning) and infāq (spending). The kasb (earning) is from al-tijārah (trade) and al-șinā'at (manufacturing skills), while infā $q$ is the function of infāq ijtimá'i (common expenditure), infāq dìni (religious expenditure) and aliddikhār (savings). Finding of this study is that the concept of managing the wealth derived from Ibn Sīnā is still relevant to the modern concept of Islamic wealth management.
\end{abstract}

Keywords: Al-Kasb, Consumption, Infāq, Model Building

\section{INTRODUCTION}

Islamic civilization has accumulated an extremely rich literary heritage that encompasses knowledge acquired through revelation and reasoning or rational knowledge. This process encouraged the earlier Muslim thinkers to study both types of knowledge and to make significant contribution to the ummah. As a result, many books have been produced in areas such as Fiqh, Hadith, Kalam (theology) Tasawwuf, and philosophy. This literature also contains some economic ideas.

Jurists, theologians, sufis and philosophers have also contributed to the Islamic economic thought. There were numerous books on fiqh, kalam, philosophy and tasawwuf which were related to economic ideas such as in al-kharaj of Abu Yusuf and Ihya ulumuddin of Imam Ghazali. Hence, the growth of Islamic economic thought has been through the development of Islamic law (Shari'ah) which is associated with economic, social and religious life of the Muslims.

According to Sabri Orman, the source of Islamic economic thought is divided into two further categories: (1) independent work forming different literature (general source) and (2) single independent (or unique, special work). ${ }^{1}$ Therefore, a study of Islamic economic thought still needs to be made in order to compare the past economic ideas to modern economics. According to Nejatullah Siddiqi's survey

1 Sabri Orman. "Source of the History of Islamic Economic Thought," in Al-Shajarah 3 no. 2 (1997): 1. 
(1981) of the history of Islamic economic thought, the economic ideas of Muslim thinkers like Ibn Khaldun, Ibn Taimiyyah, Abu Yusuf, Yahya bin Adam, Abu Ja'far Dimashqi, Imam Ghazali, Abu Ubayd, Al-Maqrizy, Al-Satibi, Nizam al-Mulk alTusi. Abu Dhar al-Ghifari, and Shah Waliullah have been studied in detail. ${ }^{2}$ However, study of the economic thought of other Muslim thinkers, especially Muslim philosophers such as Ibn Rushd, al-Farabi and Ibn Sīnā is yet to be made. It cannot be denied that they were influenced by Greek thought in philosophy, which also contains economic ideas. For instance, al-Farabi appealed to economic ideas of Plato, Aristotle ${ }^{3}$ and Ibn Sīnā, while relating the divisions of practical philosophy. ${ }^{4}$

Therefore, it is important to trace the economic ideas from philosophical perspective. According to Ibn Sinā, al-hikmah (philosophy) is divided into two categories: 'ilm nadhori (theoretical philosophy) and 'ilm 'amali (practical philosophy). ${ }^{5}$ His economic ideas are placed under three headings: Ahklāq, 'ilm Tadbir al-Manzil and ilm Tadbir al-Madinah. The possible translations, for the three major divisions of practical philosophy according to Orman, are ethics, household management and politics. ${ }^{6}$ Although Ahklāq contains certain information related to economics, the other two branches of practical philosophy ( $\mathrm{ilm}$ Tadbir al-Manzil and ilm Tadbir al-Madinah) are more about the sources of Islamic economic thought. Generally, this practical philosophy explains how household management will correlate with the state in order to bring justice and welfare in it. This study aims to explore Islamic economic thinking from Ibn Sīnā's perspective. However, it will be limited to the study of wealth management of Ibn Sinnā. It will also be related to his tadbir al-manzil (economics) to develop a theoretical model of wealth management that integrates the material, spiritual, moral, social and legal dimensions.

\section{Ibn Sinā and His Contribution to Islamic Civilization}

This section will present an overview of Ibn Sīnā and his contribution to Islamic civilization, especially in the economic area.

\footnotetext{
2 Muhammad Nejatullah Siddiqi, Muslim Economic Thinking: A Survey of Contemporary Literature (UK: The Islamic Foundation. 1981), 122-124.

3 Louis Baeck, “The Economic Thought of Classical Islam,” Diogenes 154, (1991): 101.

4 Sabri Orman, Intercivilizational Exchange of Knowledge in the Intellectual Tradition of Islam: A Case Study on the Relationship between Islam's 'Ilm Tadbir Al-Manzil and Ancient Greek's Oikonomia, (Islam Hadhari Bridging Tradition and Modernity), ed. Mohamed Ajmal Abdul Razak Al-Aidrus, (Kuala Lumpur, Malaysia: ISTAC, 2009), 249.

5 Ibn-e-Sinā, Al-Shifa/Al-Hilahiyyat, (Kairo: al-hay'a al-'am li syu'ūni al-mathābi' alamiriyyah, 1960), 3; Ibn Sinā. Avicenna on The Divisions of the Rational Sciences, translated by Muhsin Mahdi, The Medieval Political Philosophy, ed. Ralph Muhler, Muhsin Mahdi, (New York: Cornell University Press. 1986), 96-97.

6 Sabri Orman. Source of the History of Islamic Economic Thought. 1.
} 


\subsection{The Author}

Ibn Sinā (full name Abu 'Ali al-Husain 'Abdillah Ibn Hasan Ibn 'Ali Ibn Sinā), was born in August 980 CE (Safar, 370 A.H) and brought up in the kingdom of the Samanids. He is known in the West as "Avicenna", which comes through Hebrew into Latin. There are two opinions regarding his birth place. Some say that Ibn Sinā's birth was in a large village near Bukhārā called Afsahānah, his mother's native land. ${ }^{7}$ Others say that he was born in Khairmaitan, close to Bukhārā. ${ }^{8}$ Afsahānah is the most mentioned and also understandable because that was the place where his parents married and his father took up residence. ${ }^{9}$

His father, Abdullah, was from Balkh, a town known to the Greeks as Bactria, located in northern Afghanistan. According to Afnan (1958), Balkh was an important commercial and political metropolis, the intellectual and religious capital of the Muslim East. Furthermore, in the reign of Amir Nūh ibn Mansūr, Ibn Sinā moved from Balkh to Bukhārā. Then, he joined public service and was appointed as local governor in Khairmaitan. ${ }^{10}$

Ibn Sinā's father was married to a woman named Sitāra. ${ }^{11}$ His father was an Ismā'ilī. This is significant because of the Ismā'ilī's inclination towards philosophy and mysticism. Obviously, his family's interest in philosophy caused his interest in the subject:

From them, he (my father), as well as my brother, heard the account of the soul and the intellect in the special manner in which they speak about it and know it. Sometimes they used to discuss this among themselves while I was listening to them and understanding what they were saying, but my soul would not accept it, and so they began appealing to me to do it (to accept the Ismā'ilī doctrine). And there was also talk of philosophy, geometry and Indian calculation. ${ }^{12}$

The pursuit of knowledge in Ibn Sinā's time became an interesting activity for the people which gained momentum during the translation movement of the $8^{\text {th }}$ and the $9^{\text {th }}$ centuries. This movement of translation promoted and established the tradition of translation and Greek, Indian and Persian works were translated into Arabic in the $10^{\text {th }}$ century. The important works mostly influenced Ibn Sinā's education until he became a great Muslim scholar of his time.

7 Muhammad 'Abdurrahman Marhabā Minal Falasifa al-Yūnāniyyah ila al-Falasifah alIslāmiyyah (Beirut: Mansyūrāt 'awīdāt, 1970), 474; D. Gutas, "Avicenna: Biography”, in Encyclopedia Iranica, Vol. III, Ed. E. (Yar-Sharter. Mazda Publisher, 1987), 69.

8 Soheil M. Afnan, Avicenna: His Life and Works (London: George Allen \& Unwin Ltd, 1958), 57.

9 William E. Gohlman, The Life of Ibn Sinā: A Critical Edition and Annotated Translation (New York: State University of New York Press, 1974), 17-18.

${ }^{10}$ Zainal Abidin Ahmad, Negara Adil Makmur Menurut Ibnu Siena (Jakarta: Penerbit Bulan Bintang, 1974), 106.

${ }^{11}$ William E. Gohlman, The Life of Ibn Sinā,17.

${ }^{12}$ William E. Gohlman, The Life of Ibn Sinā, 18-21. 
His early education was at home, where Persian and anti-Muslim traditions were still full of life and vigor. ${ }^{13}$ A teacher of the Qur'ān and literature was provided to him, and then at age 10, he finished the Qur'ān and many works of literature. Additionally, he studied Indian calculation from a vegetable seller. At 16, he studied fiqh from Ismail al-Zahid, language from Abu Bakar Ahmad Ibn Muhammad alBarqi al-Khawarizimi. He also studied al-mantiq (logics) and architecture. His first logic teacher was Abū 'Abdullah al-Nātilī who introduced him to Isasoge and geometry.

After completing his learning from al-Nātilī, he moved to other cities and devoted himself to study the original and commentary texts on natural science, metaphysics and medicine. ${ }^{14}$ Al-Farabi was his indirect teacher in philosophy and the study of his book on metaphysics enabled Ibn Sinā to have a thorough understanding of Aristotle's metaphysics. He read it forty times. He completed the study of philosophy at the age of 18. The library of Sultān Nūh Ibn Mansūr gave him access to all sources of philosophy for his philosophical training. ${ }^{15}$

Another discipline that contributed to his study of Islamic literature was medicine. He had turned to this subject before he completed his study of philosophy. For him, studying medicine was much easier than philosophy, as he said:

Next I sought to know medicine, and so I read the books written on it. Medicine is not one of the difficult sciences, and therefore I excelled in it in a very short time, to the point that distinguished physicians began to read the science of medicine under me. ${ }^{16}$

By that time, his theoretical medicine came into practice through helping the sick. For instance, when Sultān Nūh Ibn Mansūr fell ill, Ibn Sinā was appointed to treat him. The successful treatment of the Sultan contributed a lot to his reputation and he became well-known as a master of medicine among the physicians. Therefore, he was called as syaikh al-räis because of his mastery in the field of medicine. Later, he was enrolled in the Sultān's service. At the same time, he continued to study law.

Furthermore, Ibn Sinā started active life at the age of 20 after the death of his father. His adult life as a physician, philosopher and companion of the Amir (nadim al$a m \bar{\imath} r$ ) during an unstable time, was filled with practice and he sometimes faced obstacles that made it difficult to record his own original thoughts. He undertook a number of careers besides that of a physician at the Prince's palaces. Politically he served as one of companions of the Amīr (nudama al al-amīr) Hamadan ${ }^{17}$, as an advisor to Sultan Nuh II bin Mansur from Samaniyah in 1097, and as advisor to Sulthan al-Daulah in Isfahan from 1022-1037. His job forced him to move from

${ }^{13}$ T. J. De Boer, The History of Philosophy in Islam, translated by Edward R. Jones, (England: Curzon Press, 1903), 131.

${ }^{14}$ Muhammad 'Abdurrahman Marhabā, Minal Falasifa al-Yūnāniyyah ila al-Falasifah alIslämiyyah. 474.

${ }^{15}$ Philip K. Hitti, Makers of Arab History (London, Melbourne, Toronto: Macmillan, 1968), 202.

${ }^{16}$ William E. Gohlman, The Life of Ibn Sinā, 26-27.

${ }^{17}$ William E. Gohlman, The Life of Ibn Sinā, 50-51. 
Bukhārā to Gurganj, where Abu al-Husain al-Sahli was a minister. In Gurganj, he became a lawyer with a salary that was sufficient to meet his basic needs. ${ }^{18}$

Besides serving in the government, Ibn Sinā made certain journeys to other cities after visiting Gurganj such as to Nasā, Bāward, Tus, Samangān, Khurāsān, and then Jurjān. The purpose of going to Jurjān was to serve Amīr Qābūs, but unfortunately, before his arrival there, Qābūs lost his throne, was imprisoned and died. ${ }^{19} \mathrm{He}$, then continued his journey to Dihistān and then returned to Jurjān. He met Abu Ubaid alJuzjani who later wrote Ibn-e-Sinā's biography on his request. ${ }^{20}$

\subsection{Contribution to Islamic Civilization}

Islamic civilization is a social system that helps believers to increase their cultural output. According to al-Sibā'i (2005), Islamic civilization comprises of four elements, namely, economic resources, political system, moral traditions, and science and arts. ${ }^{21}$ During the Abbasid caliphate, Islamic civilization was at its peak, supported by all elements of civilization, with Baghdad as the new capital and center of literature, art and trade. During this time, Muslim scholars were under the influence of the Greeks, Aramaics and Indians. For instance, the Greeks influenced literature and philosophy, while the Indians influenced sciences, particularly medicine, mathematics and astronomy. This period was known for what is termed historically as the "Translation movement", with Baghdad as the centre of education. In the quest for knowledge, men travelled from all over the world to Baghdad. The famous representatives of Greek knowledge among the Muslims of the $9^{\text {th }}$ and $10^{\text {th }}$ centuries, al-Kindi, al-Farabi, Abu Sulaimān al-Mantiqī as-Sijistānī and al-'Amiri. Al-Biruni (973 CE) were influenced by Indian knowledge.

Consequently, Ibn Sinā emerged as a Muslim thinker whose works embraced the entire domains of sciences and all knowledge of his own time as well as that of recent ages. His great contribution to Islamic civilization also influenced Western civilization. His works were used in European universities from the $13^{\text {th }}$ to the $18^{\text {th }}$ centuries. Ibn Sinā's book on medicine was one of the books, besides al-Razi, alHawi, that were taught in European universities. Therefore, in the West, he is known as Avicenna. He also wrote minor works on theological matters and a famous treatise on logic, physics, mathematics and astronomy called "al-Shifä", which is still being used in many universities around the world. ${ }^{22}$

\footnotetext{
${ }^{18}$ Ibid., 41.

${ }^{19}$ William E. Gohlman, The Life of Ibn Sinā, 41; A. J. Arberry and Thomas Adam, Avicenna: His Life and Times (Avicenna: Scientist \& Philosopher), ed. G.M. Wickens, (London: Luzac \& Company, Ltd, 1952), 20.

${ }^{20}$ William E. Gohlman, The Life of Ibn Sinā, 43.

${ }^{21}$ Mustafa al-Sibā'i, Civilization of Faith: Solidarity, Tolerance, and Equality Information Built on Shari'ah (Riyadh: International Islamic Publishing, 2005), 61.

${ }^{22}$ Muhammad Sohail, Administrative and Cultural History of Islam (New Delhi: Adam Publisher \& Distribution, 2002), 578.
} 
Besides his contributions to Islamic philosophy and medicine, many other writings are attributed to him; according to M. Afnān (1958):

There are a good many minor treatises attributed to Ibn Sinā not all of which are authentic. One of these, the authenticity of which has been reasonably established, is entitled the book of Politics (kitāb al-siyāsa) ${ }^{23}$

This treatise, according to Rosenthal (1992), "is devoted to ethics and economics and regimen of the household which comprises the master of the family, his wife, children and servant." ${ }^{24}$ It has been edited by many scholars such as F. Louis Ma'luf, Taysir Shaikh al-Ard, 'Abd al-Amirz Shamsuddin and Fu'ād al-Mun'im Ahmad. This book is mostly related to household management and political economy of the state. Some contemporary Muslim thinkers such as Yassine Essid, Sabri Orman, Rosenthal and Ghanzafar have acknowledged Ibn Sinā's contribution to economic literature (tadbir al-manazil) in the Islamic civilization. Accordingly, his contributions are very important and valuable in the history of Islamic civilization. He is one of the Muslim thinkers whose contributions are well known and are still being studied today.

\section{Literature Related to Wealth Management}

Wealth management is not just about investments. It is a comprehensive way of managing wealth. It takes time to really understand life's goals, both professional and personal. Historically, the management of wealth became a major concern in human civilization, prior to and after advent of Islam. The fact is that Maloney (2007) studied wealth management in the proto city of Mesopotamian Civilization. His study is limited to Sumer, which was located in southern Iraq, also known as southern Mesopotamia. He attempts to see the relationship between the aspect of wealth management and the civilization. To him, wealth management makes clearer the interplay between various factors by applying accounting practices to various activities of city life such as social, economic and political. ${ }^{25}$ Therefore, wealth management can be termed as application of comprehensive financial concepts.

In modern time, there are four steps in the process of wealth management: 1) wealth creation; 2) wealth accumulation; 3) wealth protection; and 4) wealth distribution. Wealth creation is the beginning of the process that implies several ways of creating wealth such as employment, self-employment, inheritance, compensation, gift and trade. ${ }^{26}$ In wealth accumulation, Huggett (2002) says that there is positive slope between wealth accumulation and earning risk. So when individual and aggregate wealth accumulation increases, earnings risk increases. ${ }^{27}$ His study focuses on precautionary wealth accumulation in order to reduce risk in the process of earning

${ }^{23}$ Soheil M. Afnan, Avicenna: His Life and Works, 11-19.

${ }^{24}$ E. I. J. Rosenthal, Political Thought in Medieval Islam, 142.

${ }^{25}$ Ken Maloney, Wealth Management in Proto-Cities (USA: California University Domingues Hills, 2007), 38.

${ }^{26}$ Sadalai Rasban, Personal Wealth Management for Muslims (PWMM), (Singapore: HTHT Advisory Services Pte Ltd, 2006), 28.

${ }^{27}$ Mark Hugget, "Precautionary Wealth Accumulation," Review of Economic Studies, 71, (2004): 769. 
wealth. To Heer (2001), wealth is much more unequally distributed than earnings. ${ }^{28}$ His focus of analysis is to examine inheritance taxation in three sectors of economy: the household sector, the production sector and the government. The results are that wealth inequality increases after accounting for inherited bequest and inheritance taxes increase both equality and welfare. ${ }^{29}$

Consequently, William S. Comanor and Robert H. Smiley (1975) attempt to estimate the impact of past and current enterprise monopoly profits on the distribution of household wealth in the United States. The finding is that past and current monopoly has had a major impact on the current degree of inequality in this distribution. ${ }^{30}$ These studies are using interest as variable in process of wealth management.

The concept of Islamic wealth management has also supported the development of Islamic banking and finance in the world economy. Its process of wealth management is not different from the conventional approach. It just adds the element of wealth purification that is important to achieve balanced happiness in the world and the hereafter. It is derived from the Islamic sources. As mentioned in the previous section, the source of Islamic economic thought is divided into two categories: (1) independent work forming different literature (general source) and (2) single independent (or unique) work (special work). ${ }^{31}$

Regarding the concept of wealth management, there are some Muslim thinkers whose works contain the ideas of wealth management beside the primary sources: 1) al-Qur'an and 2) Sunnah. Accordingly, Essid (1995) in his book, briefly discusses Ibn Sīnā's concept in 'ilm Tadbir al-Manzil which is included in kitāb al Siyāsa. According to him, Ibn Sīnā begins his treaties with an introduction on the necessity of administration and governance of human aspects of life; why men need dwelling and why they must congregate in families. It is specifically concerned with management of the household which looks at the responsibility of all family components in conducting the household in a proper manner. ${ }^{32}$

Bonner (2001) refers to the work attributed to al-Shaybānī that focuses on poverty, surplus, and the circulation of wealth. To him, it roughly corresponded to the questions of acquisition, consumption, charity, surplus and so on that took different meanings and forms. ${ }^{33}$ Mustafa Omar Mohammad (2009) attempts to investigate the

\footnotetext{
${ }^{28}$ Burkhar Heer, "Wealth Distribution and Optimal Inheritance Taxation in Life-Cycle Economies with Intergenerational Transfer," The Scandinavian Journal of Economics 103 no. 3 ( 2011): 445 .

${ }^{29}$ Ibid, 458.

${ }^{30}$ William S. Comanor \& Robert H. Smiley, "Monopoly and the Distribution of Wealth," The Quarterly Journal of Economics, 89, No. 2 (May, 1975).

${ }^{31}$ Sabri Orman, "Source of the History of Islamic Economic Thought," 1.

${ }^{32}$ Yassine Essid, A Critique of the Origin of Islamic Economic Thought (New York: E.J. Brill, 1995).

${ }^{33}$ Michael Bonner, "The Kitāb al-kasb Attributed to al-Shaybānī: Poverty, Surplus, and the Circulation of Wealth," Journal of the American Oriental Society, 121, No. 3 (Jul. - Sep., 2001): 410- 427.
} 
economic ideas of al-Imam Mohammad Ibn al-Hasan al-Shaybani (1986), focusing on his levels of $a l-K a s b$. His study uses al-Shaybani's levels of $a l-K a s b$ to develop a theoretical Infaq model that integrates the material, spiritual, moral, social and legal dimensions. ${ }^{34}$ These studies correspond to the concept of wealth management that includes the process of wealth management.

Another important work related to the concept of wealth management is Kitab alIsyarah ila Mahasin al-Tijarah written by Ja'far al-Dimasqi. His work consists of the meaning of wealth, wealth creation and types of consumption from Islamic perspective. Furthermore, Essi (1992) in his study focuses on the relationship of Greek economic thought in the Islamic Milieu by comparing the thoughts of Bryson and Dimashqi. ${ }^{35}$ His work focuses on trade and the accumulation of wealth more favorably than did Ibn Khaldun. ${ }^{36}$ Al-Dimasqi indicates measures essential to the accumulation and protection of wealth. ${ }^{37}$ Thus, these three works are related to the concept of wealth management.

Essid (1995) in his book has made a brief discussion of Sinā's concept in 'ilm Tadbir al-Manzil. According to him, Sinā begins his treatises with an introduction on the necessity of administration and governance of human aspect of life. ${ }^{38} \mathrm{Ibn}$ Khaldun says in his muqaddimah that the Siyāsat al-madaniya is the management of household or of a state in keeping with the demand of ethics and wisdom, so that the whole may be led on a path on which regularity is maintained. ${ }^{39}$ Ali Abbas Murād (1999) said that according to Ibn Sīnā, the management or the government of al-madinah al-fädilah should be based on the Shari'ah which consists of Ibadah and Muamalah. Muamalah refers to economic thought discussing the matters of human, social, division of work, and rules of economics in condition of al-madinah al-fādilah. $^{40}$

Zainal Ahmad (1974) also discusses the economic thought of Sinā in his book titled "Negara Adil Makmur Menurut Ibn Sinā" which means "Just and Prosperity State on Ibn Sinā’s Perspective." "41 Ahghari (1991) in his dissertation titled "The Origin

${ }^{34}$ Mustafa Omar Mohammed, Infāq Model Based on al-Shaybani's Levels of al-Kasb, International Conference on Islamic Economics and the Economies of OIC Countries, Istana Hotel, (29 April 2009).

${ }^{35}$ Yassine Essid, "Greek Economic Thought in the Islamic Milieu: Bryson and Dimashqi" in S. Todd Lowry (ed.) Perspectives on the History of Economic Thought (Hampshire: Edward Elgar, 1992), 31-38.

${ }^{36}$ Josep J. Spengler, "Economic Thought of Islam: Ibn Khaldun," Comparative Studies in Society and History, 6, No. 3 (Apr., 1964): 282.

${ }^{37}$ Ibid.

38 Ibid, 185-186.

39 First Encyclopedia of Islam 1913-1936, Vol VII ed. M.TH. Houtsma, A.J. Wensinck and H. A. R. Gibb, W. Heffening and E. Levi-Provencal, (New York: E.J. Brill, 1987), 595.

40 'Ali Abbas Murād, Daulah al-Shari'ah: Qirāatu fi Jadilah al-Din wa al-Siyasah 'inda Sinā,( Beirut: Darul al-Talı̄'ah, 1999), 121-154.

${ }^{41}$ Zainal Abidin Ahmad, Negara Adil Makmur Menurut Ibnu Siena (Jakarta: Penerbit Bulan Bintang), 1974. 
and Evolution of Islamic Economic Thought" mentioned Ibn Sinā as one of the philosophers who contributed to the developing history of Islamic economic thought in a short treatise on tadbir al-manzil. Sinā considered tadbir al-manzil as elements of political community, social organization, and management of income and expenditure. $^{42}$

\section{Wealth Management Concept of Ibn Sīnā}

Ibn Sīnā divided his wealth management into two categories: (1) seeking or earning wealth (kasb) which is described in economic term as income, and (2) using or spending the wealth earned (infäq) which is termed as expenditure. ${ }^{43}$ Both should be carried out in the right way (halal) which has been stated in the Sharì'ah. As mentioned in Ibn Sinā's book for politics, man's living should be earned through Halal or permissible ways, and not from greedy, shady or cruel means. Therefore, wealth should be earned through ways allowed by Qur'an and Hadith.

Regarding infāq (expenditure), Ibn Sinā explains the kinds of infāq in this statement: If man acquired his wealth by just ways, he must spend half of his wealth on sadaqah, zakat, good virtue, and another half should be saved for the future in case of emergency or for old age. ${ }^{44}$ In other words, under al-tawhìd, man may consume according to his need. The rest of his income or wealth should be spent on charity in the cause of Allah, or reinvested in business. ${ }^{45}$ In al-Qur'an Allah said: "...hey ask thee how much they are to spend: Say: what is beyond your needs...." This verse, according to Yusuf Ali, explains: We should use the wealth we need and any superfluities we must spend in good work or in charity. ${ }^{46}$

Therefore, members of the Muslim society should earn and spend their wealth according to permissible ways and this will benefit them here in this world and the hereafter. Currently, many people earn their wealth through wrong means such as corruption, gambling, and deceit. This wealth is also spent in unlawful ways. Such people will be punished in this world and the hereafter. For example, those who lose in gambling are punished in the form of poverty, family problems and uncomfortable life. A painful doom awaits them in the hereafter as well.

\subsection{Income and Classification of Occupation}

The economic activities of human beings increase when the needs are more varied. These activities create several ways in order to earn livelihood. According to Sinā, wealth or income can be acquired in two ways: al-warätsah (inheritance) and al$k a s b$ (earning). Those who acquire from the inheritance don't need any efforts to

\footnotetext{
${ }^{42}$ Zohrel Ahghari, The Origin and Evolution of Islamic Economic Thought, Ph.D Dissertation, (The Florida State University, 1991), 105.

${ }^{43}$ Ibn Sinā, Kitab al-Siyāsah. ed. Louis Ma'luf, in Louis Cheikho et. al, Maqālat Falsafiyyah Qadīmah li Ba'di Masyāhīrih Fālāsifah al- 'arab Muslimin wa Nasara (Beirut: al-Matba' al-Kātsūì̄kiyyah lil Abāi al-yasū'iyyin, 1911), 9-10.

${ }^{44}$ Ibid.

45 Ismāil Rājī al Fārūqi, Al Tawhid: Its Implication for Thought and Life (Virginia; US: IIIT 1998), 180.

46 Al-Qur'an, 2: 219,
} 
earn the wealth. This inheritance is acquired by the man from his father or ancestors enjoying a good living. Others have to struggle to earn the rizq. ${ }^{47}$ This division is not meant to pamper those who receive inheritance, but only to distinguish two main groups in terms of wealth.

On this point, he divided labor into two categories: trade (al-tijārah) and manufacturing skill (al-sin $\left.\bar{a}^{\prime} a t\right)$. To him, the manufacturing skill (al-sinā'at) is stronger and more stable than trade. Trade is less reliable as it depends on wealth which is inclined to disappear, and because it runs into failures and calamities. It is agreed that trade or other financial system that has used the wealth for investment is more risky than any profession that man has adopted in his life. Nevertheless, if wealth is managed properly in trade, it will gain more profit than what man has got in his work as profession. Therefore, Sina thinks that trade is more risky than the manufacturing skill. It is a warning to man to be careful in managing his wealth in trade. According to him, al-sinā 'at acquired by man is divided into three categories:

1. The intellectual sphere (hiyaz al- 'aql) including good opinion, right advice and good governance, such as the profession of ministers, managers, policy-makers, and kings.

2. The literary sphere (hiyaz al-adab), which is manifested in creative writing, $a l$ baläghah, astronomy, and medicine. These are called men of culture (al$u d a b \bar{a})$.

3. The sphere of physical strength and bravery (hiyaz al-yad wa al-syajä'a), such as the profession of knights and craftsmen.

Additionally, he emphasizes that man must choose his work from these skills in order to acquire wealth in conformity with the Shari'ah. To make his work effective, man must master his work skill by training himself to be an expert in his particular work or profession. Conversely, when something is done by the person who is not an expert in the particular work or manufacturing skill (al-sina 'at), it will cause harm and disadvantage to the society. He should also know that there is nothing finer in man than a large income that matches his merits. Moreover, he should earn through profession or work on the basis of his skills in the most modest and decent manner, avoiding greed, excessive charge or underground gain.

On the contrary, there are some prohibited professions that need to be avoided for the benefit of society. The first is the profession which causes the transfer of properties or services without giving any benefits such as gambling. Indeed, the gambler gets something without rendering any service. Rather, what one takes must always be a compensation or return for work, a compensation that is either substance, utility, or any other thing considered a human good.

The second is the professions which are opposed to welfare and benefit of society such as learning of theft, brigandage, leadership of criminal bands. The third is the professions that allow people to dispense with learning those crafts pertaining to the association - professions such as usury, as is prohibited. Usury is the seeking of

${ }^{47}$ Zainal Abidin Ahmad, Negara Adil Makmur Menurut Ibnu Siena, 188-190. 
excess profit without practicing a craft to achieve it, even though it does render a service in return.

\subsection{Division of Infā $q$ (Expenditure)}

Expenditure means the wealth or income which is spent for consumption and saving. According to Ibn Sinā, infāq (expenditure) can be divided into three categories:

1. Infāq (expenditure) for man himself and his relatives without stinginess, negligence and extravagance. It is called as infāq ijtimā'I or ' $\bar{a} m$.

2. Infāq (expenditure) for the acts of virtue (abwāb al-ma'rüf), sadaqa, and zakat. It is called as infāq dīni or khäs.

3. Al-iddikhār (saving) for future needs, emergencies, calamities and disaster.

The first category requires that man should use his consumptive expenditure (nafaqah) economically. This expenditure should be free from extravagance and stinginess. Therefore, a reasonable man should agree with the society in meaning of extravagance and stinginess and should be careful about expenditures which may be included in these categories. Sinā said that more people glorify extravagance than economy, whereas those who glorify economy and prefer assessment have more distinctive and perfect reason, and strong opinion.

The second expenditure can be carried out if man has excess resources. For instance, zakat should be paid if the wealth has reached a nisab or the man is categorized as muzakki, while sodaqoh does not need a nisab. Moreover, zakat and sodaqah should be paid in a pleasant spirit, with good intention, and confidence that expenditure either from zakat or sodaqoh is preparation for the time of need. ${ }^{48}$ The acts of virtue (abwāb al-ma'rūf) should fulfill the requirements that Sinā stated: First, it should be given immediately, because it will reassure the people in need. Secondly, it should be given secretly, because giving in secret is free from show off. Thirdly, it should be considered as small, because it means greater when giving alma'rüf. Fourthly, it should be done continuously. And lastly, it should be given in the right place and to the people who are eligible. ${ }^{49}$

The last category of spending is al-iddikhār (saving). According to Ibn Sinā, man should not forget about saving when there is a possibility. This is because sometimes man faces difficult times as his earning is small. He needs additional resources or saving for such times. However, man must believe that Allah is the best provider and the best protector. ${ }^{50}$

\section{Conceptualization of the Economic Model}

Ibn Sīnā's economic thought can be summarized in Figure 5.1. Man, as vicegerent of Allah on this earth, has two main responsibilities, worship of God (faith) and good management (economics). Firstly, man as a creation of Allah must serve and

\footnotetext{
48 Ibn Sinā, Kitab al-Siyāsah, 10.

${ }^{49}$ Ibid.

${ }^{50}$ Ibid, 11.
} 
worship Him as mentioned in Surah al-Zäriyah ,"I have created Jins and men that they may serve me." ${ }^{51}$ Worship means submission in all aspects of life as commanded by God through His laws. It is a mechanism through which man can be directed to act according to His Will (His rules), and thus, attain the position of His vicegerency. Secondly, the vicegerency of man is to develop the earth, mostly utilizing the resources given by God. It is mentioned in Surah al-A'raf, "We have placed you with authority on earth, and provided you therein with means for the fulfillment of your life: small are the thanks that ye give". ${ }^{2}$

Therefore, the responsibility of vicegerency is to benefit from the resources (wealth) bestowed by Allah, which leads to the development of the earth through hard work in order to achieve the goal in this world and the hereafter. As for income, man should earn to sustain his life through various kinds of work such as trade and other manufacturing skills that are mentioned in Ibn Sīnā's classification of occupation. After acquiring wealth or income, man should allocate or spend (expenditure side) his wealth in three ways, namely: personal spending, religious spending and saving. All forms of economic activity must be bound by the Shari'ah in order to achieve justice, which is the objective of the Shari'ah.

51 Al Quran, 51:56

52 Al Quran, 7:10. 


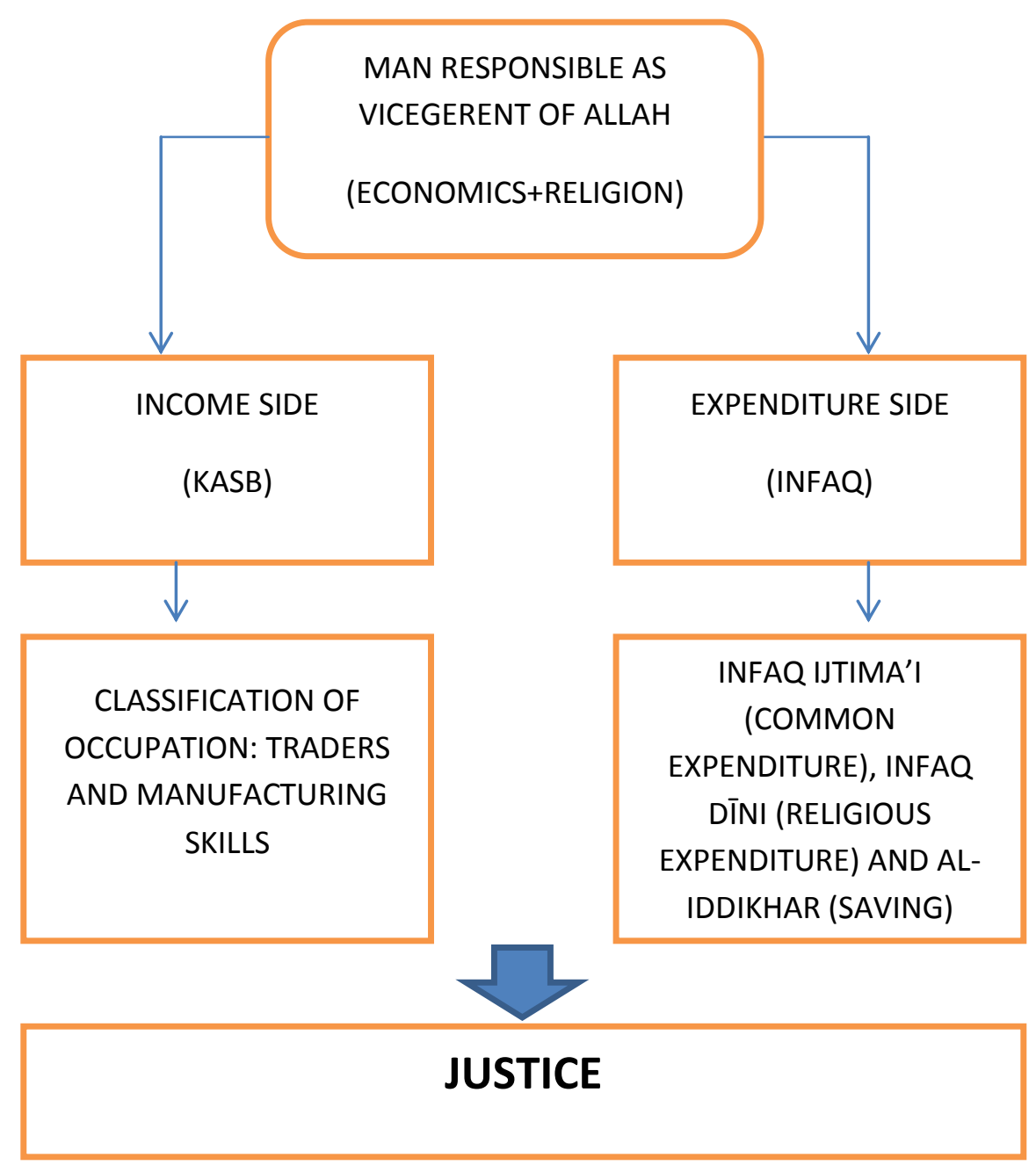

Figure 5.1 Ibn Sīnā's Idea of Managing Wealth 
Furthermore, based on Ibn Sīnā's concept of wealth management in Section 5 and Figure 5.1, it can be represented by equation (1) below:

$\mathrm{KS}=\mathrm{f}(\mathrm{T}+\mathrm{S})$

where KS is al-Kasb, $\mathrm{T}$ is al-tijärah (trade) and $\mathrm{S}$ is al-sina'at (manufacturing skills) .

Therefore, as mentioned in Ibn Sīnā's wealth management ideas, man should acquire wealth in a just way (sirat al- 'ádilah), he must spend half of his wealth on shodaqoh, zakat, acts of virtue, and another half of his wealth should be saved for the future in preparation of old age or sudden accidents. Hence, the interpretation of just way (sìrat al- 'ädilah) could be a balance between kasb and infāq, which should cover dunyawi and akhirah needs. This relationship is presented in equation (1) below:

$\mathrm{KS}=\mathrm{IQ}$

where, KS is al-Kasb and IQ is Infäq

Infāq thus corresponds to $a l-K a s b$ in terms of Ibn Sīnā's wealth management ideas:

$I Q=f\left(I_{i}+I_{d}+I_{i d}\right)$

where, $\mathrm{I}_{\mathrm{i}}$ is infāq ijtimā' $I$ (common expenditure), $\mathrm{I}_{\mathrm{d}}$ is infāq dīni (religious expenditure) and $\mathrm{I}_{\mathrm{id}}$ is al-iddikhār (saving)

Hence, infāq ijtimā' $i$ (common expenditure) is represented by

$I_{i}=f\left(N_{s}+N_{f}+N_{r}\right)$

where $\mathrm{N}_{\mathrm{s}}$ is the basic needs for one's self, $\mathrm{N}_{\mathrm{f}}$ is the basic needs for family and $\mathrm{N}_{\mathrm{r}}$ is for relatives. At this level of infāq, it is compulsory for every individual to fulfill his basic needs, to spend for the basic needs of his family members and his relatives.

At the second level of infāq, it is assumed that the individual has fulfilled all the infāq required at the first level of infāq in equation 3.

$I_{d}=f(Z+S q+A M)$

where, $\mathrm{Z}$ is zakat, $\mathrm{Sq}$ is Shadaqoh and $\mathrm{AM}$ is abwäb al-ma'rüf.

At this level, the individuals should spend the rest of kasb for zakat, shadaqah and $a b w a \bar{b}$ al-ma'rūf. It is so mentioned in Ibn Sīnā's notion this is called infāq dīni (religious spending), because there is a rightfully determined share in wealth of man for this purpose.

Last level is $\mathrm{I}_{\text {id }}$ is al-iddikhār (saving), is represented by

$I_{i d}=f(S)$ 
This third level is meant for the future needs or unforeseen expenditures. This refers to infāq model based on al-Syaibani's levels of $k a s b .{ }^{53}$

This equation does not only apply to the household, but also to the corporate sector or the government. In aggregate level, this equation (1) will contribute to economic growth. By avoiding excessive and wasteful consumption, the distribution of wealth can be efficiently done for the economic growth of the state through infāq ijtimā'I $\left(\mathrm{I}_{\mathrm{i}}\right)$, infāq dīni $\left(\mathrm{I}_{\mathrm{d}}\right)$ and al-iddikhār (saving), which is allowed in Islam $\left(\mathrm{I}_{\mathrm{id}}\right)$. From the individual side, the reward of infāq dīni will be given in the hereafter, while saving will be rewarded in the form of profit or return from the saving or investment. Then, for the benefit of the society, infāq dinni will help a mustahik or a needy person to improve his economic condition. The saving or investment will strengthen the economic sector through instruments of Islamic finance and capital market known today as products of Islamic banking, takaful or sukuk.

\section{CONCLUSION}

The wealth management of Ibn Sinā is comprehensive; it explains the fundamental aspect of work, and how wealth should be acquired and spent properly in the light of Islamic principles and values. According to him, wealth can be acquired by two ways, namely: al-warätsah (inheritance) and al-kasb (earning). Both variables can be associated with the term of wealth creation in modern times. Furthermore, all income should be spent efficiently in three steps of expenditure for future life, 1) consumptive spending, 2) religious spending and 3) saving. Indeed, this beneficial concept, as Ibn Sinā has explained, is derived from the sources of Islam: al-Qur'an and al-Hadiths. For example in al-Qur'an: “...They ask thee how much they are to spend: Say: what is beyond your needs.... ",

In modern time, this scheme can be implemented in household, corporate and government sectors. However, it is different from the Western concept which eliminates religious spending. In Islam, however, great stress is laid on religious spending, i.e., zakat, sodaqoh and al'ma'ruf that can be categorized as wealth purification in modern concept of wealth management. Besides, al-iddikhār (saving) can be included in wealth accumulation and protection because saving, in his view, is in anticipation of future events. Lastly, wealth management in Islam not only manages worldly life but also prepares for the hereafter. Therefore, let's turn to the source of Islam in order to attain better life in both the worlds.

\footnotetext{
${ }^{53}$ Mustafa Omar Mohammed, Infāq Model Based on al-Shaybani's Levels of al-Kasb, International Conference on Islamic Economics and the Economies of OIC Countries, Istana Hotel, (29 April 2009).

${ }^{54}$ Al Quran, 2:219.
} 


\section{SELECTED BIBLIOGRAPHY}

Al-Qur'an: Text, Translation and Commentary by Abdullah Yusuf Ali, Dārul Arābiyyah: Beirut.

1. Abidin, Ahmad Zainal. Negara Adil Makmur Menurut Ibnu Siena. Jakarta: Penerbit Bulan Bintang, 1974.

2. Ahghari, Zohrel. The Origin and Evolution of Islamic Economic Thought. Unpublished doctoral dissertation, Florida: The Florida State University, 1991.

3. Al Fārūqi, Ismāil Rājī. Al Tawhid: Its Implication for Thought and Life. USA: IIIT, 1998.

4. Al-Shaybani, Muhammad b. al-Hasan. al-Iktisab Fi al-Rizq al-Mustatab. $1^{\text {st }}$ Edited by Abu Ghuddah, 'Abd al-Fattah. Beirut: Dar al-Bashair al-Islamiyyah, 1997.

5. Al-Shaybani, Muhammad b. al-Hasan. al-Iktisab Fi al-Rizq al-Mustatab. $1^{\text {st }}$ Edited by 'Arnus, Mahmud. Beirut: Dar al-Kutub al-'ilmiyyah, 1986.

6. Al-Sibā'i, Mustafa. Civilization of Faith: Solidarity, Tolerance, and Equality Information Built on Shari'ah. Riyadh: International Islamic Publishing, 2005.

7. Avicenna. The Divisions of the Rational Sciences, translated by Muhsin Mahdi, The Medieval Political Philosophy, ed. Ralph Muhler, Muhsin Mahdi, New York: Cornell University Press, 1986.

8. Bonner, Michael. "The Kitāb al-kasb Attributed to al-Shaybānī: Poverty, Surplus, and the Circulation of Wealth," Journal of the American Oriental Society, 121, No. 3 (Jul. - Sep., 2001): 410-427.

9. Comanor, William S. \& Smiley, Robert H. Monopoly and the Distribution of Wealth, The Quarterly Journal of Economics 89, No. 2 (May, 1975): 177-194.

10. De Boer, T.J. The History of Philosophy in Islam. translated by Edward R. Jones, England: Curzon Press, 1903.

11. Essid, Yassine. A Critique of the Origin of Islamic Economic Thought. New York: E.J. Brill, 1995.

12. First Encyclopedia of Islam 1913-1936. Vol VII ed. M.th. Houtsma, A.J. Wensinck and H.A.R. Gibb, W. Heffening and E. Levi-Provencal, New York: E.J. Brill, 1987.

13. Galston, Miriam. Realism and Idealism in Avicenna's Political Philosophy. The Review of Politics, Vol. 41, No. 4. (1879).

14. Ghanzafar, S.M. and Islahi, A. A. "Economic Thought of an Arab Scholastic: Abu Hamid al Ghazali", History of Political Economy, Durham (USA): Vol. 22, No. 2, (Spring 1990): 381-403.

15. Ghanzafar, S.M. and Islahi, A.A. "Economic Thought of an Arab Scholastic: Abu Hamid al Ghazali", History of Political Economy 22.2 (1990): 381-403.

16. Gohlman, William E. The Life of Ibn Sinā: A Critical Edition and Annotated Translation. New York: State University of New York Press, 1974. 
17. Gutas, D. Avicenna: Biography, in Encyclopedia Iranica, Ed. E. Yar-Sharter. Vol. III, Mazda Publisher, 1987.

18. Heer, Burkhar. "Wealth Distribution and Optimal Inheritance Taxation in LifeCycle Economies with Intergenerational Transfer," The Scandinavian Journal of Economics 103, no. 3 (2011): 445-465.

19. Huggett, Mark. "Precautionary Wealth Accumulation." Review of Economic Studies, 71. (2004): 769-781. www.WileyBlackwell.com

20. Husairi, Ahmad. Al-Siyāsa Al-Iqtisadiyah wa al-Nuzum al-Maliyah fi al-Fiqh al-Islami. Cairo: Maktabah al-Kulliyat al-Azhariyah, 1982.

21. Ibn Ibrahim, Abu Yusuf Ya'qub, Kitab al-Kharaj. Cairo: Al-Matba'ah Salafiyyah, 1302 A.H.

22. Islahi, A.A., Economic Concepts of Ibn Taimiyah. Leicester: The Islamic Foundation, 1988.

23. Islahi, Abdul Azim. Thirty Years of Research in the History of Islamic Economic Thought: Assessment and Future Directions. MPRA paper, No. 18102 (2009), academic search premier via MPRA, http://mpra.ub.unimuenchen.de. (accessed, December, 23 2010).

24. Islahi, Abdul Azim. Thirty Years of Research in the History of Islamic Economic Thought: Assessment and Future Directions, MPRA paper No. 18102 academic search premier via MPRA, http://mpra.ub.uni-muenchen.de.

25. M. Afnan, Soheil. Avicenna: His Life and Works. London: George Allen \& Unwin Ltd, 1985.

26. Mahdi, Muhsin. (trans). "Avicenna on the Divisions of the Rational Sciences" The Medieval Political Philosophy. ed. Ralph Muhler and Muhsin Mahdi, New York: Cornell University Press, 1986.

27. Maloney, Ken. Wealth Management in Proto-Cities, Thesis, USA: California University Domingues Hills, 2007.

28. Marhabā, Muhammad 'Abdurrahman. Minal Falasifa al-Yūnāniyyah ila alFalasifah al-Islāmiyyah. Beirut: Mansyūrāt 'awīdāt, 1970.

29. Marmura, Michael. (trans). Avicenna on Metaphysics X: Medieval Political Philosophy. Edited by Ralph Learner and Muhsin Mahdi, USA: Macmillan Company, 1986.

30. Mohammed, Mustafa Omar. Infāq Model Based on al-Shaybani's Levels of al$K a s b$. International Conference on Islamic Economics and the Economies of OIC Countries, (Istana Hotel, 29 April 2009).

31. Murād, Ali Abbas. Daulah al-Shari'ah: Qirāatu fi Jadilah al-Din wa alSiyasah 'inda Ibn Sina. Beirut: Darul al-Talī’ah, 1999.

32. Orman, Sabri. Source of the History of Islamic Economic Thought. AlShajarah, Vol. 3. No. 2, Kuala Lumpur: ISTAC Publication, 1997.

33. Rasban, Sadalai. Personal Wealth Management for Muslims (PWMM). Singapore: HTHT Advisory Services Pte Ltd, 2006.

34. Rosenthal, Erwin I. J. Political Thought in Medieval Islam: an Introductory Outline. Cambridge University Press, 1968. 
35. Rosenthal, Franz. The Classical Heritage in Islam, translated from German by Emile and Jenny Marmorstein. London: Routledge, 1992.

36. Siddiqi, Muhammad Nejatullah. Muslim Economic Thinking: A Survey of Contemporary Literature. UK: The Islamic Foundation, 1981.

37. Sin̄ā, Ibn. Al-Syifa fi al-Ilāhiyyat. Kairo: al-hay'a al-'am li syu' ūni al-mathābi' al-amiriyyah, 1960.

38. Sinā, Ibn. Kitab al-Siyāsah. ed. Louis Ma'luf, in Louis Cheikho et. al, Maqālat Falsafiyyah Qadīmah li Ba'di Masyāhīrih Fālāsifah al- 'arab Muslimin wa Nasara, Beirut: al-Matba' al-Kātsūlīkiyyah lil Abāi al-yasū'iyyin, 1911.

39. Spengler, J.J. Economic Thought of Islam: Ibn Khaldun. Comparative Studies in Society and History, 6, No. 3 (Apr., 1964): 268-306.

40. Wilson, Rodney and el-Ashker, Ahmad. Islamic Economics: A Short History, Leiden: Brill, 2006.

41. Zakaria, Idris. The Political Aspects of Avicenna's General Theory of Cosmology and the Human Soul. Malaysia: Penerbit University Kebangsaan Malaysia, 2002. 